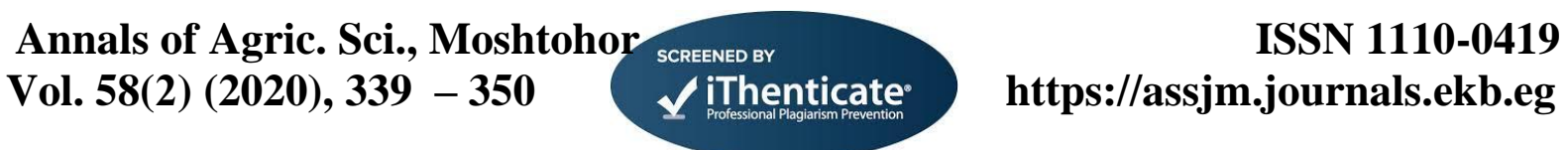

\title{
Effect of Thinning Treatments on some Physical and Chemical Fruit Characters of Barhy and Magdool Date Palm Cultivars
}

\author{
Atawia, A.A.R. El., El-Akkad, T.A.M. and Hassan, T.M. \\ Horticulture Department, Faculty of Agriculture, Benha University, Egypt.
}

\begin{abstract}
This investigation was conducted during 2017 and 2018 seasons on 10-years-old trees of date palm (Phoenix dactylifera L.) Barhy and Magdool date palm cultivars grown in a loamy sand soil at a El-Wahat Bahariya, $10 \times 10$ $\mathrm{m}$ away from each other and watered by drip irrigation system to compare the differences in their growth, fruit physical and chemical characteristics. The selected trees from the two cultivars devoted for such study were strong, healthy, grown under the same air conditions and received the same agricultural practices usually done for date palm strand thinning treatments (control, 51020 and $40 \%$ ) and the spathe thinning treatments (20\% and $40 \%$ ).

The results of this study have shown that means of fruit set (\%) and fruit physical parameters of the two cultivars expressed as fruit weight (g), fruit flesh weight (g), fruit length and fruit diameter (cm) were significantly improved by the various used combinations, with some exceptions compared to the control means in the two seasons. The highest values was for strand thinning treatment $(40 \%)$ and $(10,20 \& 40 \%)$ in fruit set (\%) in Barhy $\mathrm{cv}$, as well as $(40 \%)$ of strand thinning treatment and $(40 \%)$ in spathe thinning treatment in both seasons. Also, the thinning treatments $(5 \% \& 10 \%)$ and $(10 \%)$ and $(5,10,20$ and 40$)$ the best of fruit weight of Barhy and Magdool, in both seasons, respectively. As well as non significant in fruit/thinning (20 and $40 \%)$ with both Barhy and Magdool cvs., in both seasons of study. The best results for fruit flesh weight with the thinning treatment $(5 \%)$ and $(10,40$ and $5 \%)$ and (20\%) with Barhy cv., also, (5 and 5 or 10\%) and non significant between (20 and $40 \%$ ) for Magdool cv., for the specific effect; the highest values for the interaction effect between thinning treatment (bunch thing x fruits/strand) (5\% or $10 \%$ x $20 \%)$ and (5\% x $40 \%)$ for Barhy and Magdool cvs. In the first season (2017); in the second season (2018) (10 x $20 \%$ ) with Barhy cv., (5, $10 \%$ x 20 or 40\%) with Magdool $\mathrm{cv}$. The best results for fruit length $(\mathrm{cm})$ were the thinning treatments $(5 \%)$ and $(20 \%)$, also the interaction treatment with $(5 \%$ x $20 \%)$ for Barhy cv., in both seasons. On the other side, the highest values from the thinning treatments (5, 10, 20 and $40 \%)$ and $(40 \%)$ as well as (10\% x 40\%) in interaction effect in 2017 and 2018 seasons. The best values was the specific effect for fruit diameter $(\mathrm{cm})$ was non significant in the two cultivars (Barhy and Magdool) date palm, the superiority treatment for the interaction effect was with (5\% x 20 or $40 \%$ ) in the two cultivars in both seasons. The highest values for the total sugars and TSS for the thinning treatments $(10 \%)$ and $(10 \& 20 \%)$, also non significant in $(20 \%$ or $40 \%)$ in both seasons of study. As well as the combination treatments there variance in the two parameters and seasons. The acidity parameters non significant in all thinning treatments specific and combined in two seasons.

Hence, it can be recommended to thinning of date palm cvs. Bary and Magdool grown in sand loamy soil, $(5,10,20$ and $40 \%)$ or ( 20 or $40 \%)$ depending on every variables during the growing season to get the best results for fruit physical and chemical quality of the resulted date palm.
\end{abstract}

Keywords: Date palm (Phoenix dectylifera L.) cvs. Bary and Magdool, Thinning treatments, fruit physical, fruit chemical.

\section{Introduction}

Date palm (Phoenix dactylifera L.) belongs to the family Acaraceae and it is considered the tree of life in the desert, because it tolerates high temperatures, drought and salinity more than many other fruit crops (Lunde, 1978). Successful orchard management practices include appropriate fruit thinning which gave the retained fruits a better chance to develop with larger size and better quality. Also, it helps to overcome alternate bearing problem beside helps to have good flowering in the following year (Nixon, 1935, $1951 \&$ 1955), El-Fawal, (1962), Hussein, (1970 a) and Hassaballa et al., (1983).

Fruit thinning of several date palm cultivars in the opinion of many investigators was found to greatly improve and increase the fresh weight (g), fruit flesh weight $(\mathrm{g})$ fruit length and diameter of date fruit as compared with the control (Nixon, 1935, 1936 \& 1955; El-Fawal, 1962; Hussein, 1970; Hassaballa et al., 1983; Moustafa et al., 1984 and Khalifa et al., 1987). Khalifa et al., (1987) found that fruit thinning increased date fruit weight and the increment was in direct proportion to the amount of thinning as well as its increased date fruit dimensions. Hassaballa $\boldsymbol{e t}$ al., (1983) noticed that average fruit weight of "Zaghloul" dates was markedly increased with both strands shortening and strands removal treatments. A similar trend was found for both flesh weight and fruit dimensions. The seed fresh weight was not affected by any of the used fruit thinning treatments. Fruit thinning by strands shortening however, was more 
effective as it improved fruit physical properties of "Zaghloul" dates than the strands removal. Also, Moustafa et al., (1984) found that fruit thinning clearly increased fruit length and diameter as compared to those unthinned. In addition removing one-half of the total number of strands from the center of each hunch maximized fruit length and diameter in both seasons. Khalifa et al., (1987) and El-Makhtoun et al., (1995) observed that pulp weight of fruits and flesh percentage were increased in thinned bunch compared with unthinned bunches of "Zaghloul" date palm. Hussein (1988) found that fruit thinning 4 weeks a liar pollination caused the maximal increase of fruit length and diameter of Haiani date palms. Hussein et al., (1993 a) in their studies on "Samani" cv., reported that removing $20 \%$ of strands length after fruit set accompanied by using $\mathrm{GA}_{3}$ at $100 \mathrm{ppm}$ increased fruit weight, fruit length and diameter. The best thinning treatment was found to be cutting back tips of strands to reduce the initial fruit load by $30 \%$ at the time of pollination. Behseresht $\boldsymbol{e t}$ al., (2007) thinned bunch of "Kabkab" date cultivar by different methods at chimiri and pollination stages. They found that thinning in Chamrry stage had not significant effects on fruit quality when compared with at pollination stage. Amin et al., (2007) with "Haiany" and "Halawy" date cultivars, found that $20 \%$ removal of total number of bunch strands by either thinning out or cutting back before pollination was beneficial treatment to increase fruit chemical properties. Many investigators such as Al-Mughrabi et al., (1993); Dawoud (1998); Bamiftah (2001); Mahmoud et al., 2003); Al-Obeed, et al. (2005); Kaur et al., (2006); Marashi and Mousavi (2007);
Soliman and Harhash (2012). They reported that some thinning treatments generally improved the fruit physical characteristics as evident in increase fruit weight, size and uniformity compared to the control. Harhash (2001) mentioned that fruit thinning increased fruit chemical properties of "Seewy" dates such as TSS and sugar (total, reducing and nonreducing) while decreased tannins content.

The ultimate aims of this investigation is to find out the effect of some thinning treatments on fruit set, some physical fruit characteristics and some chemical composition of both Barhy and Magdool date palm cultivars.

\section{Materials and Methods}

The present investigation was carried out during two successive seasons (2017 and 2018) at Bahariya Oasis district, Egypt. Female Barhi and Madgool dates palms of healthy, nearly homogenous in growth as well as fruiting ability were selected and $10 \times 10 \mathrm{~m}$ away from each other and watered by drip irrigation system to comparison to the differences in their fruit physical and chemical properties. The selected palms were strands thinning \% by removing (20 and $40 \%$ ) from bunch numbers and cutting $(5 \%, 10,20$ and $40 \%)$ from spathe and combined between them, as well as the control during both seasons of study. The selected Barhi and Madgool palms were subjected to all Horticultural practices applied to the date palms in this region except those ones under study.

Chemical and physical properties of the soil analysis were done according to the procedures of Jackson (1973) as shown in Table (1).

Table 1. Physical and chemical analysis of the experimental soil.

\begin{tabular}{|c|c|c|c|c|c|c|c|c|c|c|}
\hline \multicolumn{4}{|c|}{ Particle size distribution (\%) } & \multirow{2}{*}{ S.P. } & \multirow{2}{*}{$\begin{array}{c}\text { E.C. } \\
(\mathrm{dS} / \mathrm{m})\end{array}$} & \multirow{2}{*}{$\mathrm{pH}$} & \multicolumn{4}{|c|}{ Cations (meq/L) } \\
\hline Coarse sand \% & Silt \% & Clay \% & Textural class & & & & $\mathrm{Ca}^{++}$ & $\mathrm{Mg}^{++}$ & $\mathrm{Na}^{+}$ & $\mathrm{K}^{+}$ \\
\hline 97.50 & 1.50 & 1.00 & Sand & 24.00 & 1.88 & 7.98 & 6.00 & 3.00 & 11.40 & 0.40 \\
\hline \multicolumn{4}{|c|}{ Available } & & & & \multicolumn{4}{|c|}{ Anions $(\mathrm{Meq} / \mathrm{L})$} \\
\hline $\mathrm{P}$ & $\mathrm{K}$ & $\mathrm{Fe}$ & $\mathrm{Zn}$ & Mn & $\mathrm{Cu}$ & SAR & $\mathrm{HCO}_{3}$ & $\mathrm{CO}_{3}^{--}$ & $\mathrm{Cl}^{-}$ & $\mathrm{SO}_{4}^{--}$ \\
\hline 29.07 & 48.89 & 13.28 & 0.63 & 4.07 & 1.09 & 5.4 & 6.00 & 0.00 & 7.60 & 7.20 \\
\hline
\end{tabular}

\section{Data and Measurements:}

1-Fuit set percentage: Calculated according to the following equation:

Total No. of setted fruits/bunch

Fruit set $\%=\frac{}{\text { Total No. of calyxes on the strands/bunch }}$

\section{Fruit physical properties}

Thirty fruits were randomly taken, at harvest time, as a sample for each palm during both seasons of study. Samples fruits were divided into three groups; each of 10 fruits treated as a replicate to determine the following characteristics:

\section{2-1. Fruit weight (g).}

It was calculated by weighing each of 10 fruits as a replicate. The average fruit weight, in grams, was tabulated.

\section{2-2. Flesh weight (g).}

It was calculated by weighing each of 10 fruits, as a replicate, after removing seeds. The average fruit weight, in grams, was tabulated.

\section{2-3. Fruit dimensions.}

Fruit length and diameter were measured using individual fruits of each replicate (10 fruits) by using vernier caliper. In addition, fruit length (L) per fruit diameter (D) was calculated as L/D ratio for each palm tree.

\section{Fruit chemical properties.}

Thirty fruits were randomly taken at harvest time as a sample for each palm during both seasons of the study. Samples fruits were divided into three groups 
(10 fruits of each). Each group was treated as a replicate to determine the following characteristics.

\section{3-1. Total soluble solids (T.S.S. \%).}

It was determined in fruit juice using Carl Zeiss Refractmeter as described in A.O.A.C. (1995).

\section{3-2. Fruit acidity percentage}

It was determined as described and the titratable acidity was calculated as malic acid determined in fruit juice according to A.O.A.C. (2005).

3-3. Total sugars content.

It was determined according to Dubois et al., (1966) in the methanol extract using the phenol sulfuric acid method; and the concentration was calculated as $\mathrm{g} / 100 \mathrm{~g}$ fresh weight.

\section{Statistical analysis:}

Data were then tabulated and the morphological ones are subjected to analysis of variance using the computer program of SAS Institute (2009) that followed by differences between treatments Means were separated by the (New L.S.D) (Waller and Duncan 1969) least significant differences test at a 0.05 probability level.

\section{Results and Discussions}

\section{Effect on fruit set $(\%)$.}

\section{A- Specific effect:}

Regarding the fruit set (\%) of Barhy date palm cv., as affected by specific effect of strands thinning treatments (control, 5, 10, 20 and $40 \%$ ), data obtained during 2017 and 2018 seasons as shown from Table (2) displayed obviously that fruit set $(\%)$ responded specifically to the investigated thinning treatments whereas $(20 \%, 10 \%$ and $40 \%)$ treatments in the first season and treatment of $(20 \%)$ in the second one were exhibited significantly the highest percentage of fruit set, followed in a descending order by treatment of (5 $\%)$ in the first season and the treatment of $(40 \%)$ in the second one. However, the control treatment showed statistically the least values in fruit set $(\%)$ in the two seasons of study. As for the fruit set $(\%)$ of Magdool cultivar, data in the same Table showed clearly that the highest value of fruit set (\%) was always in significant relationship to the (40\%) thinning treatment in both the first and second seasons of study. On the contrary, the least statistical values of fruit set (\%) of Magdool cv., was in concomitant to the control treatment in the two seasons. On the other hand, other remain thinning treatments came descendingly an intermediate from the standpoint of statistic the abovementioned two extents.

Concerning the specific effect of spathe thinning treatments i.e., $(20 \%$ and $40 \%)$ on fruit set $(\%)$ of both Barhy and Magdool date palm cultivars, data in Table (2) revealed that the thinning treatment of (40 $\%$ ) was resulted significantly in the greatest increase in fruit set (\%) in both 2017 and 2018 seasons of study with the two studied cultivars i.e., (Barhy and Magdool). Anyhow, the differences between the two investigated thinning treatments were significant as they were compared each other. Whereas, the differences of Barhy cv., were relatively less pronounced than those found with the differences of Magdool cv., Such trends were detected during both 2017 and 2018 seasons of study.

Table 2. Effect of thinning treatments on fruit set (\%) of Barhy and Mgdool date palm cultivars during 2017 and 2018 seasons.

\begin{tabular}{|c|c|c|c|c|c|c|}
\hline \multirow{3}{*}{$\begin{array}{l}\text { Date palm cv. } \\
\text { Bunch thinning }\end{array}$} & \multicolumn{3}{|c|}{ Barhy date palm } & \multicolumn{3}{|c|}{ Magdool date palm } \\
\hline & \multicolumn{6}{|c|}{ Thinning (fruits/strand) } \\
\hline & $20 \%$ & $40 \%$ & Mean & $20 \%$ & $40 \%$ & Mean \\
\hline & \multicolumn{6}{|c|}{ First season; 2017} \\
\hline Control & 64.94d & 67.52c & 66.23C & $55.46 \mathrm{e}$ & 64.37c & 44.92E \\
\hline $\mathbf{5 \%}$ & $68.73 \mathrm{c}$ & 69.45b & 69.09B & 63.07d & $64.78 \mathrm{c}$ & 63.92D \\
\hline $10 \%$ & 71.24a & 69.68b & 70.46A & 63.43d & $66.88 b$ & 65.16C \\
\hline $20 \%$ & 69.85b & 69.94b & $69.90 \mathrm{~A}$ & $64.79 \mathrm{c}$ & $66.87 b$ & $65.83 B$ \\
\hline $40 \%$ & $69.76 \mathrm{~b}$ & $69.33 \mathrm{~b}$ & 69.55A & $64.50 \mathrm{c}$ & 68.07a & $66.29 \mathrm{~A}$ \\
\hline \multirow[t]{2}{*}{ Mean } & 68.90B & 69.18A & & $56.25 B$ & 66.19A & \\
\hline & \multicolumn{6}{|c|}{ Second season; 2018} \\
\hline Control & 65.70g & 70.42ef & 68.06D & $26.02 \mathrm{~g}$ & 63.25d & 44.64D \\
\hline $5 \%$ & $70.11 f$ & $71.61 \mathrm{c}$ & 70.86C & 61.77ef & $62.25 \mathrm{e}$ & $62.01 C$ \\
\hline $10 \%$ & $71.44 \mathrm{~cd}$ & 70.66ef & 71.05C & $64.27 c$ & $63.87 \mathrm{~cd}$ & 64.07B \\
\hline $20 \%$ & $73.28 \mathrm{a}$ & 72.37b & 72.83A & $61.34 f$ & $66.90 \mathrm{a}$ & 64.12B \\
\hline $40 \%$ & 73.76a & 71.31de & 72.54B & 63.41d & $65.89 \mathrm{~b}$ & $64.65 \mathrm{~A}$ \\
\hline Mean & $70.86 B$ & $71.27 \mathrm{~A}$ & & 55.36B & $64.43 \mathrm{~A}$ & \\
\hline
\end{tabular}

Means followed by the same letter in a column or row do not differ significantly according to Duncan`s New Multiple Range at 5\%.

\section{B- Interaction effect:}

Considering the interaction effect of the different combinations treatments between the variables of each investigated factor i.e., (strands and spathes) thinning treatments, data obtained and represented in
Table (2) displayed clearly that, the specific effect of each investigated factor was directly reflected on their combinations, whereas as the spathe thinning treatment of $(40 \%)$ was combined with the strands thinning treatments of (40\%) exhibited statistically 
the highest value of fruit set (\%). Contrary to that, the combination treatment (control x $20 \mid \%$ ) was resulted in the least significant value of fruit set (\%) of both Barhy and Magdool date palm cultivars. Cush trends were true during the first and second seasons of study. In addition to that, other combinations treatments were statistically in between the abovementioned superior and inferior extents with relatively slight variance between them during both seasons of study.

These results concerning the fruit set percentage in general agreement with the findings of Khalifa et al., (1987) and Soliman \& Osman (2001), they stated that fruit set percentage of Amhat cv., and both bartmode \& Mlkabi dates were affected by different investigated thinning treatments.

\section{Effect on fruit quality:}

2-A. Fruit physical properties:

\section{2-A.1. Fruit weight (gm).}

\section{A- Specific effect:}

Regarding the average fruit weight of Barhy date palm cultivar as influenced by the strand thinning treatments i.e., (control, 5, 10, 20 and $40 \%$ ), data obtained and tabulated in Table (3) revealed that it responded specifically; whereas the heaviest fruits were exhibited with $(5 \%)$ treated palm followed in a descending order by both $(10 \%)$ and $(40 \%)$ thinning treatments. Moreover, untreated Barhy date palms (without thinning control treatment) showed statistically the least values of fruit weight. Such trends were detected during both 2017 and 2018 seasons of study. On the other hand, the average fruit weight of Magdool date palm cv. was significantly inclosed relationship with the date palm (40 \%) treatment which induced the heaviest fruit weight. Contrary to that, the lightest fruits in their average weight were always in concomitant to those date palm untreated/control treatment. Such trend was true during both seasons of study.

As for the specific effect of spathe thinning treatment of both $(20 \%)$ and $(40 \%)$ on the fruit weight of Barhy date palm cultivar, data represented in the same Table (3) show that response was positively relationships between the $(20 \%)$ treatment and fruit weight of Barhy date palm cv. Since the heaviest fruits were significantly produced by $(20 \%)$ treatment as compared to the other treatment $(40 \%)$ which induced significantly the lightest fruits. Such trend was true during both seasons of study with respect to the response of Magdool date palm cv. to the two spathe thinning treatment i.e., $(20 \%)$ and (40 $\%$ ), data represented in Table (3) displayed that fruit weight of Magdool date palm cv., responded significantly to the two investigated treatments. However, the differences between the two treatments was significant. Moreover, the heaviest fruits was statistically resulted by the $(40 \%)$ of thinning treatment compared to another treatment $(20 \%)$ during both 2017 and 2018 seasons of study.

Table 3. Effect of thinning treatments on fruit weight (gm) of Barhy and Mgdool date palm cultivars during 2017 and 2018 seasons.

\begin{tabular}{|c|c|c|c|c|c|c|}
\hline \multirow{3}{*}{$\begin{array}{l}\text { Date palm cv. } \\
\text { Bunch thinning }\end{array}$} & \multicolumn{3}{|c|}{ Barhy date palm } & \multicolumn{3}{|c|}{ Magdool date palm } \\
\hline & \multicolumn{6}{|c|}{ Thinning (fruits/strand) } \\
\hline & $20 \%$ & $40 \%$ & Mean & $20 \%$ & $40 \%$ & Mean \\
\hline & \multicolumn{6}{|c|}{ First season; 2017} \\
\hline Control & $19.72 \mathrm{c}$ & $20.06 c$ & 19.89C & $29.28 \mathrm{~cd}$ & 28.99f & 29.14C \\
\hline $\mathbf{5 \%}$ & 20.95a & $20.28 \mathrm{bc}$ & 20.62A & 29.06ef & 29.49b & 29.27B \\
\hline $10 \%$ & 20.91a & $20.53 b$ & 20.72A & 29.53b & $29.74 a$ & 29.63A \\
\hline $20 \%$ & 20.17c & 20.14c & 20.16C & 29.14d-f & 29.16d-f & 29.15C \\
\hline $40 \%$ & $20.51 b$ & $20.25 \mathrm{c}$ & 20.38B & 29.24c-e & $29.38 \mathrm{bc}$ & 29.31B \\
\hline \multirow[t]{2}{*}{ Mean } & 20.45A & $20.25 A$ & & 29.25A & 29.35A & \\
\hline & \multicolumn{6}{|c|}{ Second season; 2018} \\
\hline Control & $20.81 f$ & $21.26 \mathrm{~cd}$ & 21.33B & 30.19e & 30.33de & $30.26 B$ \\
\hline $5 \%$ & 21.67ab & 21.66ab & $21.66 A$ & $30.66 a$ & $30.66 a$ & $30.66 \mathrm{~A}$ \\
\hline $10 \%$ & 21.85a & 21.58b-d & 21.72A & 30.58a-c & 30.72a & 30.65A \\
\hline $20 \%$ & 21.23ef & $21.64 b c$ & 21.44B & 30.64ab & $30.44 \mathrm{~b}-\mathrm{d}$ & $30.54 \mathrm{~A}$ \\
\hline $40 \%$ & 21.83a & 21.42de & 21.63A & $30.42 \mathrm{~cd}$ & 30.63ab & 30.52A \\
\hline Mean & $21.44 A$ & $21.51 \mathrm{~A}$ & & $30.50 \mathrm{~A}$ & $30.55 \mathrm{~A}$ & \\
\hline
\end{tabular}

Means followed by the same letter in a column or row do not differ significantly according to Duncan`s New Multiple Range at $5 \%$.

\section{B- Interaction effect:}

Concerning the interaction effect of the different combination between the differential variables of both investigated thinning factors on fruit weight of both date palm cultivars i.e., (Barhy and Magdool), Table (3) shows that the lightest fruit weight was significantly inclosed relationships with both Barhy and Magdool date palm cultivars treated with the thinning combinations treatment of (control x $20 \%$ ) during both 2017 and 2018 seasons of study.

Contrary to that, the heaviest fruits in their average weight were always in concomitant to those palms treated with $(10 \times 20 \%)$ thinning treatment with Barhy cultivar whereas, with Magdool cultivar the 
heaviest fruit weight was resulted by the thinning combination treatment of $(10 \times 40 \%)$. In addition, the other combination treatments were significantly intermediate regarding their interaction effect on fruit weight of both Barhy and Magdool date palm cultivars during 2017 and 2018 seasons of study.

\section{2-A.2. Fruit flesh weight (gm).}

\section{A- Specific effect:}

Regarding the fruit flesh (pulp) weight of both Barhy and Magdool date palm cultivars as influenced by the specific effect of strand thinning treatments i.e., (control, 5, 10, $2040 \%$ ), data in Table (4) shows that, it responded significantly during both seasons of study. However, both the thinning treatments of (5\% and $10 \%)$ for that Barhy cv., and (10\%) with the Magdool cv., resulted significantly in the highest values in flesh (pulp) weight. Whereas, the control treatment induced statistically the least value of flesh (pulp) weight of both Barhy and Magdool fruits during both 2017 and 2018 seasons of study.

With respect to the specific effect of the spathe thinning treatments i.e., (20\%) and (40\%) data obtained during that the highest value of flesh (pulp) weight of Barhy fruits cv., was statistically gained by thinning treatment of $(20 \%)$ as compared to the other treatment $(40 \%)$. Such trend was true during both seasons of study. On the other hand, as opposite trend was observed with the Magdool date palm cultivar since, the greatest significant value of flesh (pulp) weight of Magdool fruits was exhibited with the thinning treatment of $(40 \%)$ in the two seasons of study.

\section{B- Interaction effect:}

Considering the interaction effect of the various combinations between the differential variables of the two studied factors on flesh (pulp) weight of both date palm cultivars under study i.e., Barhy and Magdool, data obtained and represented in Table (4) shows clearly that flesh (pulp) of both Barhy and Magdool fruits responded significantly to the different thinning combinations treatments. It could be noticed that, the specific effect of each investigated factor was directly reflected on their combinations whereas, as the thinning treatment of $(20 \%)$ was combined with strand/pathe thinning treatments $(5 \%)$ and $(10 \%)$ exhibited statistically the greatest flesh (pulp) weight value during both 2017 and 2018 seasons, respectively with the Barhy cultivar. As for the Magdool cultivar the combination treatment of $(10 \% \times 40 \%)$ resulted in a significant highest value of fruit flesh (pulp) weight during the two seasons of study. On the other hand, an opposite trend was true with the thinning combination treatment of (control x $20 \%$ ) which was statistically induced the lightest flesh (pulp) weight for both Barhy and Magdool date palm fruits cultivars. Meanwhile, the other remain combinations were in between the abovementioned two extents were detected during both the first and second seasons of study.

Table 4. Effect of thinning treatments on fruit flesh weight (gm) of Barhy and Mgdool date palm cultivars during 2017 and 2018 seasons.

\begin{tabular}{|c|c|c|c|c|c|c|}
\hline \multirow{3}{*}{$\begin{array}{l}\text { Date palm cv. } \\
\text { Bunch thinning } \\
\end{array}$} & \multicolumn{3}{|c|}{ Barhy date palm } & \multicolumn{3}{|c|}{ Magdool date palm } \\
\hline & \multicolumn{6}{|c|}{ Thinning (fruits/strand) } \\
\hline & $20 \%$ & $40 \%$ & Mean & $20 \%$ & $40 \%$ & Mean \\
\hline & \multicolumn{6}{|c|}{ First season; 2017} \\
\hline Control & 18.06e & 18.61c & 18.32D & $25.64 \mathrm{~cd}$ & $25.37 f$ & 25.50D \\
\hline $\mathbf{5 \%}$ & 19.22a & 18.83b & 19.03A & $25.98 b$ & 26.15a & 26.06A \\
\hline $10 \%$ & $19.22 \mathrm{a}$ & 18.29d & 18.75B & 25.57de & 25.97b & 25.77B \\
\hline $20 \%$ & $18.54 \mathrm{c}$ & $18.47 \mathrm{~cd}$ & 18.51C & $25.51 \mathrm{e}$ & $25.48 \mathrm{e}$ & 25.49D \\
\hline $40 \%$ & $18.80 b$ & $18.54 \mathrm{c}$ & 18.67B & $25.65 \mathrm{~cd}$ & $25.67 \mathrm{c}$ & $25.66 \mathrm{C}$ \\
\hline \multirow[t]{2}{*}{ Mean } & 18.77A & 18.55B & & $25.67 A$ & $25.72 \mathrm{~A}$ & \\
\hline & \multicolumn{6}{|c|}{ Second season; 2018} \\
\hline Control & $19.72 \mathrm{e}$ & $19.51 f$ & $19.62 \mathrm{C}$ & $26.71 c$ & $26.78 c$ & $26.75 C$ \\
\hline $5 \%$ & 19.99bc & $19.93 \mathrm{~b}-\mathrm{d}$ & $19.96 \mathrm{~A}$ & 27.05a & 27.00a & $27.02 A$ \\
\hline $10 \%$ & $20.20 \mathrm{a}$ & 19.75de & $19.98 \mathrm{~A}$ & 27.09a & 27.01a & 27.05A \\
\hline $20 \%$ & $19.54 f$ & 19.94bc & 19.74B & 26.91b & 26.79c & 26.85B \\
\hline $40 \%$ & 20.09ab & 19.87c-e & $19.98 \mathrm{~A}$ & 26.93b & $26.79 c$ & 26.86B \\
\hline Mean & 19.91A & 19.80B & & $26.94 A$ & 26.87A & \\
\hline
\end{tabular}

Means followed by the same letter in a column or row do not differ significantly according to Duncan`s New Multiple Range at $5 \%$.

2-A.3. Fruit length (cm).

\section{A- Specific effect:}

With respect to the specific effect of the strand thinning treatments of (control, 5, 10, 20 and 40\%) on fruit length of Barhy date palm cultivar, data obtained during 2017 and 2018 seasons as shown from Table (5) displayed that fruit length was significantly responded to both thinning of (50\% and control) treatments which were induced statistically fruit with more elongated length than those of other three thinning treatments $(10 \%, 20 \%$ and $40 \%)$ which were completely absent from the stand point of statistic as compared to the abovementioned two treatments. Such trends were detected during both seasons of study. As for the fruit length of Magdool cv., as influenced by the specific effect of aforesaid 
treatments, data in the same Table shows that, the response was relatively less pronounced as compared to that detected with fruit length of Barhy cv., However, all thinning treatments under study except $(40 \%)$ treatment exhibited statistically the superior effect and the greatest values of fruit length. Contrary to that, the $(40 \%)$ treatment was resulted least significant value of fruit length. Such trend was true throughout 2017 and 2018 seasons of study.

Regarding the fruit length of Barhy cv., as affected by the specific effect of both spathe thinning treatments of (20\% and $40 \%)$, data obtained during both 2017 and 2018 seasons, as shown from Table (5) declared that, fruit length was significantly responded to both thinning treatments. Whereas, the thinning treatment of $20 \%$ was increased significantly the fruit length of Barhy cultivar over that of $(40 \%)$ thinning treatment. Such trend was true during both seasons of study. On the other hand, the reverse trend was observed with the specific effect of both thinning treatments $(20 \%$ and $40 \%)$ on fruit length of Magdool cultivar. Since, Magdool date palm thinned with (40 $\%)$ treatment resulted in statistically the greatest value of fruit length over $(20 \%)$ treatment. Moreover, the differences between the two investigated treatments were significant as they were compared each other during both seasons of study.

Table 5. Effect of thinning treatments on fruit length $(\mathrm{cm})$ of Barhy and Mgdool date palm cultivars during 2017 and 2018 seasons.

\begin{tabular}{|c|c|c|c|c|c|c|}
\hline \multirow{3}{*}{$\begin{array}{l}\text { Date palm cv. } \\
\text { Bunch thinning }\end{array}$} & \multicolumn{3}{|c|}{ Barhy date palm } & \multicolumn{3}{|c|}{ Magdool date palm } \\
\hline & \multicolumn{6}{|c|}{ Thinning (fruits/strand) } \\
\hline & $20 \%$ & $40 \%$ & Mean & $20 \%$ & $40 \%$ & Mean \\
\hline & \multicolumn{6}{|c|}{ First season; 2017} \\
\hline Control & $3.19 b$ & 3.04b & 3.09B & $3.49 \mathrm{bc}$ & $3.47 \mathrm{c}$ & $3.48 B$ \\
\hline $5 \%$ & $3.27 \mathrm{a}$ & $3.14 b$ & $3.21 \mathrm{~A}$ & $3.48 \mathrm{c}$ & 3.63ab & $3.56 \mathrm{~A}$ \\
\hline $10 \%$ & $2.96 \mathrm{~d}$ & $2.98 d$ & 2.97D & $3.47 \mathrm{c}$ & $3.66 a$ & 3.57A \\
\hline $20 \%$ & 2.97d & $2.99 \mathrm{~cd}$ & 2.98D & $3.50 \mathrm{bc}$ & 3.63ab & 3.57A \\
\hline $40 \%$ & $3.05 c$ & $3.00 \mathrm{~cd}$ & $3.02 C$ & $3.48 \mathrm{c}$ & $3.65 a$ & 3.57A \\
\hline \multirow[t]{2}{*}{ Mean } & 3.09A & 3.03B & & $3.48 B$ & 3.61A & \\
\hline & \multicolumn{6}{|c|}{ Second season; 2018} \\
\hline Control & $3.17 b$ & $3.10 \mathrm{c}$ & $3.14 B$ & $3.38 b$ & 3.41b & $3.40 \mathrm{~B}$ \\
\hline $5 \%$ & $3.24 a$ & $3.15 b$ & $3.20 \mathrm{~A}$ & $3.36 \mathrm{~b}$ & $3.61 a$ & 3.49AB \\
\hline $10 \%$ & 3.06de & 3.03e & 3.05C & $3.40 b$ & $3.64 a$ & $3.52 \mathrm{~A}$ \\
\hline $20 \%$ & $3.08 \mathrm{~cd}$ & 3.07c-e & 3.08C & $3.38 b$ & 3.58a & $3.48 \mathrm{AB}$ \\
\hline $40 \%$ & $3.08 \mathrm{~cd}$ & 3.06c-e & 3.07C & $3.39 \mathrm{~b}$ & $3.63 a$ & $3.51 \mathrm{~A}$ \\
\hline Mean & 3.13A & 3.08B & & 3.39B & $3.57 \mathrm{~A}$ & \\
\hline
\end{tabular}

Means followed by the same letter in a column or row do not differ significantly according to Duncan`s New Multiple Range at $5 \%$.

\section{B- Interaction effect:}

Referring the interaction effect of the different combinations treatments between the various variables of each investigated factor, data in Table (5) revealed that, the specific effect of each investigated factor was directly reflected on their combinations. Whereas, as the (5\%) of thinning treatment was combined with either $(20 \%)$ or $(40 \%)$ on thinning treatments induced significantly the highest values of fruit length of Barhy cv., in the two seasons of study. Contrary to that, the combination treatment between $(40 \%) \times(40 \%)$ resulted in the least statistically value of fruit length of Barhy cv. During both 2017 and 2018 seasons of study. Meanwhile, the other combinations treatments were in between the abovementioned two extents from the stand point of statistic during the two experimental seasons of study. On the other hand, it could be noticed that, with Magdool cv., (40\%) of spathe thinning treatments compared with all strands thinning combinations treatments exhibited statistically the greatest value of fruit length whereas, the reverse wad true with the combinations thinning treatments between the spathe thinning treatment of $(20 \%)$ from one hand combined with all the strands thinning treatments of (control, $5 \mid \%, 10 \%, 20 \%$ and $40 \%$ ) from the other which were induced statistically the least value of fruit length during both 2017 and 2018 seasons of study.

\section{2-A.4. Fruit diameter $(\mathrm{cm})$.}

\section{A- Specific effect:}

Concerning the specific of strands thinning treatments (control, $5 \%, 10 \%, 20 \%$ and $40 \%$ ) from one hand and spathe thinning treatment (20 $\mid \%$ and 40 $\%)$ treatments from another one fruit diameter of Barhy date palm cultivar, data in Table (6) indicated that the previously detected trend with fruit length also found for the other fruit dimensions (fruit diameter). In the other words, data displayed obviously that the response typically followed the same trend previously detected with the fruit length during both 2017 and 
2018 seasons of study. On the other hand, regarding the specific effect of both abovementioned factors on fruit diameter of Magdool date palm cultivar, data in the same |Table revealed that, the previously detected trend with fruit length was also observed in this respect i.e., for the fruit diameter. Such trends were detected during both seasons of study.

\section{B- Interaction effect:}

Regarding the interaction effect of various combinations treatments between the differential variables of both investigated factors on fruit diameter of either Barhy or Magdool date palm cultivars, data in Table (6) shows that, the response followed typically the same trend previously found with the former fruit dimensions (fruit length) for both studied cultivars (Barhy and Magdool) such trends were true during both 2017 and 2018 seasons of study.

The obtained results in this respect reflect the important of thinning treatment in improving of physical, fruit quality of date plams cvs. These results are in accordance with from accordance with the findings of Higazy et al., (1983); Shaheen et al., (1989); Moustafa et al., (1984); El-Kassas (1983); Nixnon (1936 and 1955); El-fawal (1962); Hussein (1970); Hassaaballa et al., (1983); Khalifa et al., (1987); El-Makhtoun et al., (1995); El-Shazly (1999), Osman and Soiliman (2001) and Soliman \& Harhash (2012) they cleared that, all thinning investigated treatments had improved fruit physical characteristics of some date palm cultivars i.e., (Seewy, Zaghloul, Nabtet Ali, Zahdi, Sakkoti, Shamaia and Balady) date palm cultivars. They reported that the investigated thinning treatments were increased significantly fruit weight, flesh weight and fruit dimensions (fruit length and diameter) as compared with the control.

Table 6. Effect of thinning treatments on fruit diameter $(\mathrm{cm})$ of Barhy and Mgdool date palm cultivars during 2017 and 2018 seasons.

\begin{tabular}{|c|c|c|c|c|c|c|}
\hline \multirow{3}{*}{$\begin{array}{l}\text { Date palm cv. } \\
\text { Bunch thinning }\end{array}$} & \multicolumn{3}{|c|}{ Barhy date palm } & \multicolumn{3}{|c|}{ Magdool date palm } \\
\hline & \multicolumn{6}{|c|}{ Thinning (fruits/strand) } \\
\hline & $20 \%$ & $40 \%$ & Mean & $20 \%$ & $40 \%$ & Mean \\
\hline & \multicolumn{6}{|c|}{ First season; 2017} \\
\hline Control & 2.39ab & $2.36 \mathrm{bc}$ & 2.35B & $2.47 \mathrm{bc}$ & $2.52 a$ & $2.50 \mathrm{~A}$ \\
\hline $5 \%$ & 2.42a & 2.40ab & 2.41A & $2.54 a$ & $2.54 a$ & $2.54 \mathrm{~A}$ \\
\hline $10 \%$ & 2.38ab & 2.27d & 2.33C & $2.46 \mathrm{c}$ & 2.50a-c & 2.48A \\
\hline $20 \%$ & $2.30 \mathrm{~cd}$ & $2.34 \mathrm{bc}$ & $2.32 \mathrm{C}$ & $2.46 \mathrm{c}$ & 2.51a-c & $2.49 \mathrm{~A}$ \\
\hline $40 \%$ & $2.35 \mathrm{bc}$ & $2.30 \mathrm{~cd}$ & 2.33C & $2.46 \mathrm{c}$ & $2.47 \mathrm{bc}$ & 2.51A \\
\hline \multirow[t]{2}{*}{ Mean } & $2.37 \mathrm{~A}$ & 2.33A & & $2.48 \mathrm{~A}$ & $2.51 \mathrm{~A}$ & \\
\hline & \multicolumn{6}{|c|}{ Second season; 2018} \\
\hline Control & $2.41 \mathrm{a}$ & $2.31 b$ & $2.36 \mathrm{~B}$ & $2.44 c$ & 2.53ab & $2.49 \mathrm{~A}$ \\
\hline $5 \%$ & $2.41 \mathrm{a}$ & 2.37a & 2.39A & $2.55 a$ & 2.53ab & $2.54 \mathrm{~A}$ \\
\hline $10 \%$ & $2.29 \mathrm{bc}$ & $2.28 b c$ & $2.29 \mathrm{C}$ & $2.43 c$ & 2.54ab & 2.49A \\
\hline $20 \%$ & $2.25 \mathrm{c}$ & $2.28 b c$ & $2.27 \mathrm{C}$ & $2.46 \mathrm{c}$ & $2.51 b$ & 2.49A \\
\hline $40 \%$ & $2.31 \mathrm{bc}$ & $2.28 \mathrm{bc}$ & $2.30 \mathrm{C}$ & $2.44 \mathrm{c}$ & $2.43 c$ & $2.44 \mathrm{AB}$ \\
\hline Mean & 2.33A & $2.30 \mathrm{~A}$ & & $2.46 \mathrm{~A}$ & 2.51A & \\
\hline
\end{tabular}

Means followed by the same letter in a column or row do not differ significantly according to Duncan`s New Multiple Range at $5 \%$.

2-B. Fruit physical properties:

2-B.1. TSS (\%).

A- Specific effect:

With respect to the influence of the strand thinning $(20 \%)$ and $(40 \%)$ treatments on fruit juice TSS \% in both date palm cultivars i.e., (barhy and Magdool), data obtained in Table (7) displayed obviously that, it could be noticed from result that, the differences in most cases were so slight and could be safely neglected from one hand, in spite of the (40\%) treatment in the second (2018) season with (Magdool) cultivar only whereas, showed a tendency to decrease TSS \% of (Magdool) fruit juice in comparison with all the other thinning treatments of $(20 \%)$ and $(40 \%)$ during both 2017 and 2018 seasons of study with the two investigated cultivars of date palm.

Referring the response of fruit juice TSS (\%) to the specific effect of spathe thinning treatments of (control, 5, 10, 20 and $40 \%$ ) data in Table (7) declared that, both investigated date palm cultivars i.e., (Barhy and Magdool) treated with any of $(20 \%)$ or $(40 \%)$ thinning treatments induced fruits contained statistically the highest values of TSS (\%) during both the first and second seasons of study. Contrary to that, the control treatment resulted in the lowest values of fruit juice TSS (\%) from the stand point of statistics. In addition to that, the other remain thinning treatments i.e., $(5 \%)$ and $(10 \%)$ were in between the abovementioned two extents. 
Table 7. Effect of thinning treatments on TSS (\%) of Barhy and Mgdool date palm cultivars during 2017 and 2018 seasons.

\begin{tabular}{|c|c|c|c|c|c|c|}
\hline \multirow{3}{*}{ Bunch thinning } & \multicolumn{3}{|c|}{ Barhy date palm } & \multicolumn{3}{|c|}{ Magdool date palm } \\
\hline & \multicolumn{6}{|c|}{ Thinning (fruits/strand) } \\
\hline & $20 \%$ & $40 \%$ & Mean & $20 \%$ & $40 \%$ & Mean \\
\hline & \multicolumn{6}{|c|}{ First season; 2017} \\
\hline Control & $28.67 b$ & 29.25ab & $28.96 B$ & 79.25bc & 78.96e & 79.11B \\
\hline $5 \%$ & 29.33a & 29.06ab & 29.20AB & 79.06de & $79.20 \mathrm{~cd}$ & 79.13B \\
\hline $10 \%$ & 29.17ab & 29.39a & 29.28AB & 79.39a-c & $79.28 \mathrm{bc}$ & 79.34A \\
\hline $20 \%$ & $29.67 a$ & 29.39a & 29.53A & $79.39 \mathrm{a}-\mathrm{c}$ & $79.53 a$ & 79.46A \\
\hline $40 \%$ & 29.33a & $29.42 \mathrm{a}$ & 29.38AB & 79.42ab & 79.38a-c & 79.40A \\
\hline \multirow[t]{2}{*}{ Mean } & 29.23A & 29.30A & & $79.30 \mathrm{~A}$ & 79.27A & \\
\hline & \multicolumn{6}{|c|}{ Second season; 2018} \\
\hline Control & $28.77 b c$ & 29.12ab & 28.95AB & 80.10de & 80.01ef & $80.06 C$ \\
\hline $5 \%$ & $28.47 c$ & 28.94bc & 28.71B & $79.98 \mathrm{e}-\mathrm{g}$ & $80.86 c$ & 80.42B \\
\hline $10 \%$ & 29.58a & 28.82bc & 29.20A & 80.80c & 79.82fg & 80.31B \\
\hline $20 \%$ & $28.42 c$ & 28.97bc & 28.70B & 81.23b & 80.28d & 80.76A \\
\hline $40 \%$ & 28.92bc & 28.82bc & 28.87AB & 81.68a & $79.79 \mathrm{~g}$ & $80.74 A$ \\
\hline Mean & 28.83A & 28.93A & & $80.76 A$ & 80.15B & \\
\hline
\end{tabular}

Means followed by the same letter in a column or row do not differ significantly according to Duncan`s New Multiple Range at $5 \%$.

\section{B- Interaction effect:}

As for the interaction effect of the various thinning treatments of $(20 / 40 \%)$ combined with the differential thinning treatment (strand $\mathrm{x}$ spathe) of (control, 5, 10, 20 and 40), data in Table (7) revealed obviously that, Barhy date palm cultivar subjected to the $(20,5,40$ \& $10 \% \times 20 \%)$ and $(10,20$ and $40 \% \times 40)$ with non significant between combination treatments fruits combined statistically the highest values of TSS (\%) in first season. Also, the second season, the thinning treatment $(10 \% \times 20 \%)$ in the highest value. The opposite trend was observed with the thinning combination treatment of (control x $20 \%$ ) and (control x 20 or 40) at Barhy and Magdool cvs., which resulted in the lowest significant value of TSS (\%).On the other hand, the other remain thinning combination treatments were in between the abovementioned the extents during both 2017 and 2018 seasons of study.

\section{2-B.2 Acidity (\%). \\ A- Specific effect:}

Considering the total titratable acidity (\%) in fruit juice in both Barhy date palm and Magdool date palms fruits in response to the specific effect of the two factors in adjusted under study i.e., (20\% and $40 \%$ ) of thinning by removing fruits/strand and (control, 5 , 10,20 and $40 \%$ ) of bunch thinning treatments, data obtained and represented in Table (8) showed clearly that the total acidity (\%) of both date palm cultivars followed typically the same trend during the seasons of study. Whereas, acidity (\%) did not respond specifically to both investigated factors abovementioned, however differences were so very little to be significant during the two seasons of study. In other words, all variables treatments i.e., (20 and 40 $\%$ thinning by removing fruits/strand) from one hand and (control, 5, 10, 20 and $40 \%$ ) bunch thinning from another showed statistically the same effectiveness in this regard.

\section{B- Interaction effect:}

Regarding the interaction effect of the different combinations between the various variables (thinning by removing fruits/strand and bunch thinning) treatments of both Barhy date palm and Magdool date palm fruits, data obtained in Table (8) revealed obviously that, the specific effect each factor i.e., $(20 \mathrm{x}$ $40 \%$ ) and (control, 5, 10, 20 and $40 \%$ ) was directly reflected on their combinations during both 2017 and 2018 seasons of study. In other words, data shows clearly very slight influence. However, all combinations were equally effective from the stand point of statistic during both seasons of study.

\section{2-B.3. Total sugars (\%).}

A- Specific effect:

Concerning the specific effect of the fruit juice total sugars content as affected by thinning treatment of $(0,5,10,20$ and $40 \%)$, data obtained and represented in Table (9) indicated obviously that the strand thinning treatment of $(10 \%)$ with Barhy date palm cultivar and the treatment of $(40 \%)$ in Magdool date palm cultivar were the superior treatments which induced the highest statistically values of fruit juice total sugars during both 2017 and 2018 seasons of study. On the other hand, the control treatment (untreated thinning) in both (Barhy) and (Magdool) date palm cultivars was the inferior treatment which exhibited the least significant values of fruit juice total sugars content. Such trend was true during both the first and second seasons of study. Moreover, the other 
thinning treatments were in between the abovementioned two extents.

Regarding the specific effect of spathe thinning treatments of (20/40) on fruit juice total sugars content, it is quite evident from tabulated data in Table (9) that the fruit juice total sugars content slightly responded, whereas the differences between both thinning treatments $(20 \%)$ and $(40 \%)$ were not significant and could be safely neglected during both 2017 and 2018 as for the Barhy date palm cultivar. However, it could be generally observed that, the thinning treatment of (40\%) induced fruits had relatively higher significant values of juice total sugars content than those of fruits treated with the thinning treatment of $(20 \%)$. Such trend was detected with Magdool date palm cultivar during both 2017 and 2018 seasons of study.

Table 8. Effect of thinning treatments on acidity (\%) of Barhy and Mgdool date palm cultivars during 2017 and 2018 seasons.

\begin{tabular}{|c|c|c|c|c|c|c|}
\hline \multirow{3}{*}{$\begin{array}{c}\text { Date palm cv. } \\
\text { Bunch thinning }\end{array}$} & \multicolumn{3}{|c|}{ Barhy date palm } & \multicolumn{3}{|c|}{ Magdool date palm } \\
\hline & \multicolumn{6}{|c|}{ Thinning (fruits/strand) } \\
\hline & $20 \%$ & $40 \%$ & Mean & $20 \%$ & $40 \%$ & Mean \\
\hline & \multicolumn{6}{|c|}{ First season; 2017} \\
\hline Control & $0.107 a$ & 0.108a & $0.107 A$ & $0.093 a$ & $0.097 \mathbf{a}$ & $0.095 A$ \\
\hline $\mathbf{5 \%}$ & $0.104 a$ & 0.103a & $0.104 A$ & $0.091 \mathrm{a}$ & $0.096 a$ & $0.094 A$ \\
\hline $10 \%$ & $0.107 a$ & $0.110 \mathrm{a}$ & $0.109 A$ & $0.095 a$ & $0.096 \mathbf{a}$ & $0.096 A$ \\
\hline $20 \%$ & 0.111a & $0.110 a$ & $0.111 A$ & $0.096 a$ & $0.091 \mathrm{a}$ & $0.094 A$ \\
\hline $40 \%$ & $0.107 a$ & $0.110 \mathrm{a}$ & $0.108 A$ & $0.093 a$ & $0.099 a$ & $0.096 A$ \\
\hline \multirow[t]{2}{*}{ Mean } & 0.107A & $0.108 A$ & & $0.094 A$ & $0.096 A$ & \\
\hline & \multicolumn{6}{|c|}{ Second season; 2018} \\
\hline Control & 0.105 & $0.105 a$ & $0.105 A$ & $0.098 a$ & $0.096 a$ & $0.097 A$ \\
\hline $5 \%$ & $0.108 \mathrm{a}$ & $0.107 a$ & 0.107A & $0.099 a$ & $0.091 \mathrm{a}$ & $0.095 A$ \\
\hline $10 \%$ & $0.105 a$ & $0.107 a$ & $0.106 A$ & $0.094 a$ & $0.094 a$ & $0.094 A$ \\
\hline $20 \%$ & $0.106 a$ & $0.110 \mathrm{a}$ & $0.108 A$ & $0.093 a$ & $0.100 a$ & $0.097 A$ \\
\hline $40 \%$ & $0.109 a$ & $0.107 a$ & $0.108 A$ & $0.095 a$ & $0.092 a$ & $0.094 A$ \\
\hline Mean & 0.107A & $0.107 A$ & & 0.096A & $0.095 A$ & \\
\hline
\end{tabular}

Means followed by the same letter in a column or row do not differ significantly according to Duncan`s New Multiple Range at $5 \%$.

Table 9. Effect of thinning treatments on total sugars (\%) of Barhy and Mgdool date palm cultivars during 2017 and 2018 seasons.

\begin{tabular}{|c|c|c|c|c|c|c|}
\hline \multirow{3}{*}{$\begin{array}{l}\text { Date palm cv. } \\
\text { Bunch thinning }\end{array}$} & \multicolumn{3}{|c|}{ Barhy date palm } & \multicolumn{3}{|c|}{ Magdool date palm } \\
\hline & \multicolumn{6}{|c|}{ Thinning (fruits/strand) } \\
\hline & $20 \%$ & $40 \%$ & Mean & $20 \%$ & $40 \%$ & Mean \\
\hline & \multicolumn{6}{|c|}{ First season; 2017} \\
\hline Control & 36.38d & 36.64cd & 36.51C & 84.45d & 85.55b & 85.00C \\
\hline $5 \%$ & $37.20 b$ & $37.20 b$ & 37.20B & 84.50d & 85.51b & 85.01C \\
\hline $10 \%$ & 38.01a & 37.52b & 37.77A & 84.56d & 85.89a & 85.23B \\
\hline $20 \%$ & 37.34b & 37.22b & 37.28B & 85.18c & $85.56 b$ & 85.37B \\
\hline $40 \%$ & 36.33d & $36.77 \mathrm{c}$ & 36.55C & 85.77ab & $85.90 \mathrm{a}$ & $85.84 A$ \\
\hline \multirow[t]{2}{*}{ Mean } & 37.05A & 37.07A & & 84.89B & $85.68 A$ & \\
\hline & \multicolumn{6}{|c|}{ Second season; 2018} \\
\hline Control & 36.51ab & 35.36f & 35.94B & 83.79e & $84.56 \mathrm{~cd}$ & 84.17D \\
\hline $5 \%$ & $35.55 \mathrm{ef}$ & $36.23 \mathrm{bc}$ & 35.89B & $84.77 c$ & 84.36d & 84.57C \\
\hline $10 \%$ & $36.63 a$ & $35.92 \mathrm{~cd}$ & $36.28 \mathrm{~A}$ & 84.48cd & $84.66 \mathrm{~cd}$ & 84.57C \\
\hline $20 \%$ & 35.58ef & $36.24 \mathrm{bc}$ & 35.91B & $84.76 c$ & 85.34b & 85.05B \\
\hline $40 \%$ & 36.52ab & 35.82de & 36.17A & $84.75 \mathrm{c}$ & 86.18a & 85.47A \\
\hline Mean & $36.16 A$ & 35.91A & & 84.51B & 85.02A & \\
\hline
\end{tabular}

Means followed by the same letter in a column or row do not differ significantly according to Duncan`s New Multiple Range at $5 \%$.

\section{B- Interaction effect:}

As for the interaction effect of the various thinning treatments of (20/40) combined with the differential thinning treatment (strand $\mathrm{x}$ spathe) of (control, 5, 10, 20 and 40), data in Table (9) revealed obviously that, Barhy date palm cultivar subjected to the $(20 \times 20)$ combination treatment induced fruits combined statistically the highest values of total sugars content.
An opposite trend was observed with the thinning combination treatment of (control x $40 \%$ ) which resulted in the lowest significant value of fruit juice total sugars content. Such trends were true during both seasons of study. On the other hand, the other remain thinning combination treatments were in between the abovementioned the extents during both 2017 and 2018 seasons of study. 
The abovementioned results of the investigated thinning treatments are in agreement with those reported by Moustafa et al., (1984); Moustafa et al., (1998); Hussein (1988); El-Kassas (1983); AlJoumayly (2003), Harhash (2001) and Amin et al., (2007), they observed that, all the studied thinning treatments improved and significantly effected on fruit chemical properties (TSS \%, Acidity $\%$ and total sugars contents) of many date palm cultivars i.e., (Haiany, Halawy, Sweey, Kheneizi and Azghloul).

\section{References}

Al-Joumayly, A.A.M. (2003). The effect of different thinning methods on three date palm cultivars in south Jordan. Abstracts of the International Conference on Date Palm. Qassem, Saudi Arabia. Sep., 2003. p. 24.

Al-Mughrabi, M.A.; El-Hamady, M.A. and Basha, M.A. (1993). Effect of thinning on fruit quality of "Seleg" and "Meneifi" date palm cultivars. Program \& Abstract of the Third Symposium on Date Palm. Al-Hassa, Saudi Arabia. Jan., 1993.p.B 24.

Al-Obeed, R.S.; Harhash, M.A. and Fayez, N.S. (2005). Effect of bunch thinning on yield and fruit quality of Succary date palm cultivar grown in the Riyadh region. J. King Saud Univ. Agric. Sci. 17(2): 235-249.

Amin, K.I.A.; El-Salhy, A.M.; Marzouk, H.M. and El-Kady, A.M. (2007). Effect of fruit thinning on yield, fruit development and its quality of "Haiany" and "Halawy" date palm cultivars. Abstracts of the Fourth Symposium on Date Palm. Al-Hassa, Saudi Arabia. May 2007. p. 114

A.O.A.C. (1995). Association of Official Analytical Chemists. Official Methods of Analysis, $15^{\text {th }}$ ed. Washington, D.C., USA.

Bamiftah, M.A.O. (2001). Effects of fruit thinning of "Madeni" dates on fruit quality and yield. Abstracts of the Second International Conference on Date Palms. Al-Ain, United Arab Emirates. March, 2001. p.27.

Behseresht, R.; Khademi, R. and Bayat, P. (2007). The effects of bunch thinning methods on quality and quantity of date palm cv. "Kabkab". Abstracts of the Fourth Symposium on Date Palm. Al-Hassa, Saudi Arabia. May 2007. p. 117:122.

Daoud, D.A. (1998). Comparison between the effect of pollen sources, thinning treatment and their combination on fruit quality of the "Zahidi" dates. Abstracts of the First International Conference on Date Palms. Al-Ain, United Arab Emirates. March, 1998. p. 3.

Dubois, M.; Smith, F.; Illes, K. A.; Hamilton, J. K. and Rebers, P. A. (1966). Colorimetric mehod for determination of sugars and related substances. Ann. Chem., 28 (3): 350-356.

El-Fawal, A.N. (1962). A study on fruit development and methods of degrees of fruit thinning in some
Egyptian date varieties. Date Grower 's Inst. Rept., 39: 3-8.

El-Kassas, S. E. (1983). Manual bunch and chemical thinning of Zaghloul date. Assiut, J. Agric. Sci., 14 (2): 221-233.

El-Makhtoun, F.M.; Abd El-Kader, A.M. and Abd El-Aal, A.A. (1995). Effect of different fruit thinning methods on yield and fruit characteristics of "Zaghloul" dates. Zagazig J. Agric. Res. 22(1): 143149.

El-Shazly, S.M. (1999). Effect of fruit thinning on yield and fruit quality of "Nabtet Ali" Saudi date palm. The International Conference on Date Palm. Nov., Assiut Univ. Center for Environmental Studies. Conference book, 17-32.

Harhash, M.M. (2001). Effect of fruit thinning and potassium fertilization on "Seewy" date palms grown at Siwa Oasis. Abstracts of the Second International Conference on Date Palms. Al-Ain, United Arab Emirates. March, 2001. p.29.

Hassaballa, I.A., Ibrahim, M.M.; Sharaf, M.M.; AbdEl Aziz, A.Z. and Hagagy, N.A. (1983). Fruit physical and chemical characteristics of "Zaghloul" date cultivar in response to some fruit thinning treatments. Annals of Agric. Sci. Moshtohor. 20(3): 314.

Higazy, M.K.; El-Ghayaty, S.H. and El-makhatoun, F.B. (1983). Effects of pollen type on fruit setting, yield and some physical fruit properties of some date varieties. Proceedings of the fruit Symposium on the Date Palm in Saudi Arabia, 84-93

Husseein, A.A.M. (1988). Effect of fruit thinning on yield and fruit quality of Hayani date palms grown in northern Sinai. Egyptian Jornal of Applied Scince, 8: 4, 25-35.

Hussein, F. (1970 a). Effect of fruit thinning on size, quality and ripening of "Sakkoti" dates grown at Asswan. Trap. Agric. 47: 2, 163-166.

Jackson, M.H. (1973). Soil Chemical Analysis. PrenticeHall of India Private Limited M-97, New Delhi, India, 498pp.

Kaur, N., Josan, J.S. and Monga, P.K. (2006). Fruit thinning of dates in relation to fruit size and quality. II. Abstracts of Poster sessions. Third International Date Palm Conference. Feb., Abu Dhabi, United Arab Emirates. p. 56.

Khalifa, A.S., El-Kady, M.I.; Abdalla, K.M. and ElHamady, A.M. (1987). Influence of thinning patterns and leaf/bunch ratio on "Zaghloul" dates. Annals Agric. Sci., Fac. Agric. Ain Shams Univ., Cairo, Egypt. 32(1): 637-647.

Lunde, P., (1978). A History of Dates. Saudi Aramco World, 29(2), pp. 176-179.

Mahmoud, H.M.; El-Mandy, T. k. and Fouad, M. A. (2003). Effect of bagging and fruit thinning treatments on yield and fruit quality of "Zaghloul" under Aswan conditions. Proceedings of the International conference on Date palm 247:259.

Marashi, S. and Mousavi, A. (2007). Effects of different methods and degrees of fruit thinning on yield and fruit 
characteristics of Barhee date cultivar. Acta Hort. (ISHS) 736: 187-192.

Moustafa, A. A. (1993). Effect of fruit thinning on yield and fruit quality of "Seewy" date palms under ElFayoum Governorate conditions. Proc. of the Third Symp. On the Date Palm. Al-Hassa, Saudi Arabia. Jan., v. I: 239-246.

Moustafa, A.A., Bondok, A.Z. and Salama, M.A. (1984). Effect of different hand thinning treatments on yield and quality of "Hayany" date fruits. Bull. Fac. Of Agric., Univ. of Cairo. 35(3): 1543-1551.

Moustafa, A.A. (1998). Studies on fruit thinning of date palms. Proceeding of the first international conference on the date palms 35-44.

Nixon, R.W. (1936). Further experiments in fruit thinning of dates. Date Growers' Inst. Rep. 13: 6-8.

Nixon, R.W. (1951). Fruit thinning experiments with the "Magdool" and "Barhee" varieties of dates. Date Growers' Inst. Rep. 28: 14-17.

Nixon, R.W. (1955). Size and checking of "Deglet Noor" dates as affected by fruit thinning and pollen. Date Growers' Inst. Rep. 32: 8-10.
Osman, S.M. and Soliman, S.S (2001). Effect of thinning on fruiting and fruit characteristics of some dry date palm cultivars under Aswan conditions. Minufiya J. Agric. Res. Vol. 26 No. 3: 845-858.

SAS, Institute. (2009). SAS/STAT User's Guides Statistics. Vers. 6.04, $4^{\text {th }}$ Ed., SAS. Institute Inc. Cary, N.C., USA.

Shaheen, M.A.; Bacha, M.A. and Nasr, T.A. (1989). Effect of male type on fruit chemical properties on some date palm cultivars. Annals of Agricultural Science, Cairo, 34 (1): 265-281.

Singh, R.: Randhawa, G. S. and Sharma, D. K. (1961). Pollen storage and pollen germination in fruit crops. Ind. Jour. Hort. 1 8:85-96.

Soliman S. S. and M. M. Harhash (2012). Effects of strands thinning on yield and fruit quality of Succary date palm. African J. of Biotechnology. 11(11): 26722676.

Waller, P.A. and D.B. Duncan (1969). A buyes rule for the symmetric multiple comparison problem. Amer. State. Assoc. J., 64: 1484-1503. 


\section{تأثير معاملات خف الثمار على بعض الخصائص الطبيعية والكيماوية لصنفي نخيل البلح البرحي والمجدول

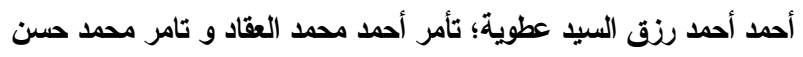 \\ قسم البساتين - كلية الزراعة - جامعة بنها - مصر .}

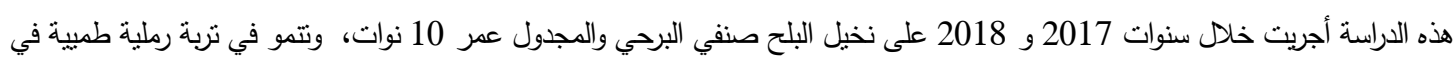

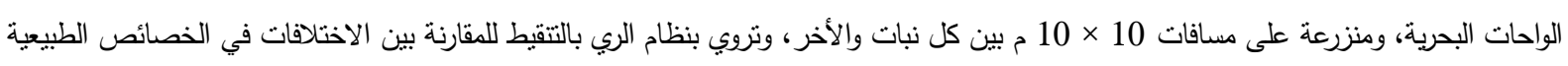

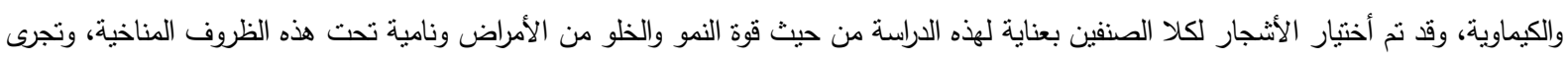

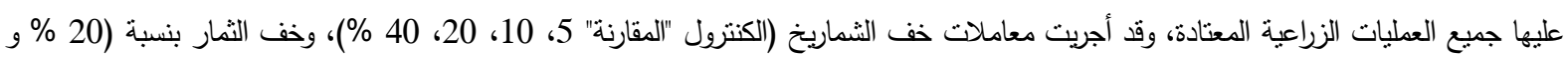

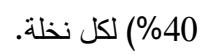

أوضحت نتائج هذه الدراسة أن متوسطات جميع متوسطات قياسات النسبة المئوية لعقد الثمار والصفات الطبيعية للثمار (وزن الثمرة،

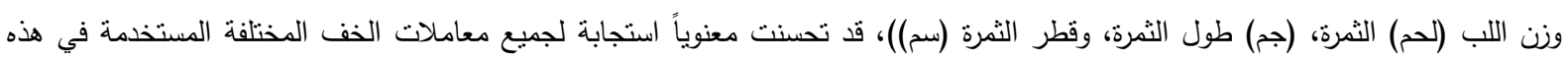

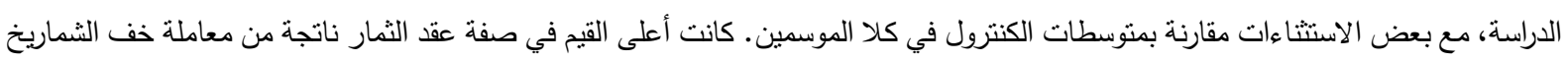

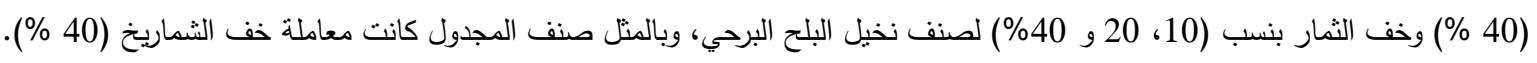

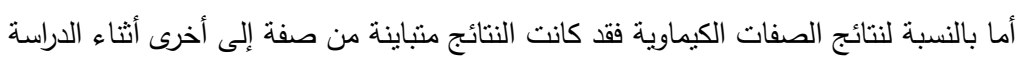

